\title{
The perception of a university's brand within the recruitment pool for future students (Case survey for the economic higher education)
}

\author{
Nicolae Alexandru POP \\ The Bucharest University of Economics Studies, Bucharest, Romania \\ nicolae_al_pop@yahoo.com \\ Steluța TODEA \\ The Bucharest University of Economics Studies, Bucharest, Romania \\ steluta.todea90@yahoo.com
}

\begin{abstract}
The brand of a university is the result of the interaction between the vectors it uses to position itself in relation to its stakeholders. Among these, high school students who aspire to become students play a key role. The way in which the university is perceived by its main recruitment base (the high school environment) is crucial for the capacity of the university to recruit the best qualified candidates. Considering there is a lack of a coherent project by either the higher education system or the secondary education system that looks into the high school students' choice of an educational trajectory, there is a need for in-depth research about the motivational mechanism that drives future students to opt for a certain university. In order to fill this gap, the present study aims to research the vectors that drive the high school students' choice of a university programme. It is a quantitative, sample research conducted on high school students in the last year of their programme, in representative high schools in one of the districts of Bucharest. The method used is the survey, the technique is that of face-to-face interviews, and the instrument used was the semi-structured questionnaire. The second research is an exploratory qualitative study conducted on the class tutors of the high school students; its purpose is to describe, with the help of some hypotheses, their preoccupations throughout the pedagogical process of career orientation. By changing the perception of the academic environment, this can help promote social cohesion and a synergy between the processes of accumulating knowledge and those of stimulating creativity and innovation in the university environment. The present study aims to contribute to this project and is based on the literature that reflects the experience of some of the most important schools in the international context, as far as the recruitment of future students is concerned.
\end{abstract}

Keywords: perception, brand, university branding, market research in the recruitment base.

\section{Introduction}

In the contemporary world, the perception of the surrounding environment in which we live and work is more important than actual reality.

This principle grounds the major interest of market research, which is focused on understanding the mechanism and the consequences of the perception of a service aimed at satisfying a human need.

\section{Literature review}

From brand to branding

The brand is an inevitably subjective summary of the people's perception of an organization, product, service, location, or even of a personality (Olins, 2009, p. 13), which 
reflects their lived emotional and functional experiences (Zyman et al. 2008) with regards to the above-mentioned elements. It is rightly said that the brand is an organization's most prized possession (Tybout et al. 2005, Zyman, 2008, Esch et al., 2008, Armstrong et al. 2015). The definition we will use throughout this study is one that makes the distinction between two related concepts and belongs to a well-known Romanian practitioner in this field - Aneta Bogdan. According to her, the brand signifies a combination of material and immaterial attributes, represented through a trademark, that are professionally managed in order to become value generators for the business they represent (Bogdan, 2010, p.34).

Today, a brand is no longer specific just to the products and the services it is connected to, being associated directly with a series of non-profit activities, with certain cities, regions, or countries, or even with certain personalities (Kotler et al. 1993, Hanna, 2008, Fan, 2010). A multi-dimensional concept, the brand is the answer to some of the psycho-social needs of those who embody demand, and relies on the functional-emotional structure of an organization (De Chernatony, et al. 1998). From among the many approaches of the various aspects of the brand, we choose the one that is the most widely encompassing, namely Wheeler's enumeration. This outlines the following features of the brand: vision, message, authenticity, uniqueness, differentiation, sustainability, coherence, flexibility, commitment and value (Wheeler, 2009).

Transposing into action the process of creating, developing, communicating and adding value to a brand has taken on the form of a philosophy for guiding the marketing action (Bogdan, 2011) that has been given the name of branding. Zyman and Brott rightly define branding as a marketing strategy and action through which a product, service, idea, location, or personality is turned into a brand (Zyman et al. 2008). Understanding the essence of this process is still made difficult in Romania because of treating the trademark and the brand as synonyms. The major difference between the two concepts is that the trademark is primarily represented by material signs (name, logo, graphics, image, sound, or a combination of these) registered by a designated organization (such as OSIM, in Romania) in order to ensure legal protection (State, 2016), while the brand becomes the symbol of the trademark, with a clear aim for occupying a superior position on the market by the products, services, institutions, or personalities.

\section{University branding - specificities in marketing services}

The universities are among the organizations that push for creating and adding value to their own brand. Over time, they have strived to develop a behaviour that is similar to that of corporations in relation to their stakeholders (Veloutsou et al. 2004). Chief among the vectors that decide the attraction of a university and, implicitly, its position in relation to the beneficiaries of its services are the satisfaction of the individuals that are educated and their belonging to a community of prestige (Krishhnan, et al. 2001, pp. 328-342).

The process of marketing education services has a multitude of specificities that are necessarily related to the object of the service, its place, its duration, but also the manner in which it is perceived by its beneficiaries. Adding value to the education service is correlated, even more so than in the case of other services, to the ability to integrate all of the stakeholders in this process. We could also say that the orientation towards integration needs to be more prominent in the case of these services (Pop et al. 2015). Given the highly heterogeneous character of the education services in general and of those provided by 
universities in particular, the marketer is confronted by the tension between the standardization versus the diversification of the elements of these services.

Appraising the quality of the university services cannot be based exclusively on standardized features such as the curricula, the syllabi, the amount of transfer credit, etc., and comparing similar study programmes is mined by subjectivity to a much larger extent than in the case of different services, such as in the field of hygiene, utilities, transport and so on, due to the main beneficiary - the student - who is driven by a very different degree of co-participation in the process of education. A future student's choice of a university and/or programme of study is a highly individualized decision, marked by personal objectives that are very much diverse, such as (Băcilă, 2013, p. 10): personal risks in the case of making the wrong decision; the personal, material and psychological costs; the impact on their personal image, etc. The degree of satisfaction experienced by the graduate of a university programme is in direct relation to their degree of involvement in accessing the services. Because of this, there is a need for ample participation on behalf of the student and a need for empathy on behalf of those providing the services.

The sequential process through which candidates select a specific set of services is key in evaluating a university brand. The demand for a place in a study programme is articulated over a period of time that varies widely - from a duration of several years, in the case of candidates that opt for a certain field during their upper secondary school years or even lower secondary school years, to a spontaneous decision once the candidate gets their baccalaureate at the end of high school. This first stage of shaping the educational endeavours can be supported by a coherent effort for communication between school university - parents - high school student. The second stage in laying the ground for a decision takes the form of identifying the type of studies one aims for and finding out their correspondent in the national and international offer of programmes of study. Finally, the third stage is that of the process of admission to a tertiary education institution, which comprises mechanisms with varying degrees of difficulty regarding the evaluation of abilities, the investment of financial resources, and the envisagement of the post-university opportunities.

\section{The perception of a university brand}

The question of university branding is placed in the frame of institutional branding (Irimieș, 2012), which is the process of putting a public or private institution in the limelight. This field has been stimulated by the development of country and city brands, which were followed by conceptualizing, along the same lines, public institutions such as hospitals, schools, universities and so on (Grigorescu, 2007). Developing competition mechanisms for the public institutions as well places an increasing demand on them to make an effort to adapt to the environment they serve. Higher education cannot disregard the effects of such a trend. The field faces, at the moment, multiple challenges. The management of the universities needs to be increasingly preoccupied by developing their own university brand in the context of competition factors determined by: competing private and public services in the field of higher education, the growth of bilateral and multilateral mobilities for students and professors, and especially the competition from programmes abroad that are attractive to the young people in Romania.

In developing a university brand, the perception of the different programmes of study of the university plays a crucial role. A programme is, however, perceived very 
differently not only by the various stakeholders, but also within the same cohort (Popa et al. 2016) by those interested in it. Gaining insight into the factors that shape perception, which eventually leads to the formation of an attitude. Of course, motivation is directly related to the satisfaction the current cohorts of university students feel and make known to the cohorts following them (Voineagu et al. 2017). Consequently, the matter of the perception of a university brand is very wide and cannot be covered by one study alone. According to the results of a 2015 research by the market research company D\&D Research (Petre, 2015) the university brand is taken into account, more and more frequently, when young people make up their mind about going to university ( $45 \%$ of the participants in the study say it is important that the university comes highly recommended, and $42 \%$ wish to attend a prestigious university).

The conclusions of a study conducted by a group of professors from Harare (Zimbabwe), who aimed to assemble a thorough review of the international literature on university branding (Erisher et al. 2014) point to various directions for research on certain relations relevant to the position of university branding, that have not been studied in depth, such as: the relation between the management of the university brand reputation on the one hand and the effect of the country of origin, or the public-private partnership, or the placement of the graduates on the labour market on the other hand, as well as the problem of re-engineering and the reconfiguration of the mission and vision of the university and brand policy.

In what follows, we have decided, among the many inciting topics, to test through a case study the perception by high school students of the brand of a study programme in a prestigious university in Romania.

\section{Methodology}

The purpose of the selective marketing research that is the object of the case study we conducted is the way high school students perceive the university they intend to gain admission to and how the brand evolves. In order to achieve this, we have decided on a set of objectives: determining the hierarchy of the reasons of a young person deciding on a track of university studies; how do the interviewed subjects perceive the brand of the university and what place does the brand have in the motivational process; what are the information vectors taken into account and what is their hierarchy in outlining a university brand; how do the school and the university respectively support the career orientation of the future high school graduates.

In order to achieve these objectives, we have conducted two selective marketing researches. The first one - quantitative - has had as subjects the students in the final year of study in seven high schools in Bucharest, all in district 1 . We started off with the expectation that these young people would be more thoroughly informed on the matter under discussion as compared to the national average. The sample, encompassing 322 valid answers, aimed for representativity for a limited area, but relevant for the elite Bucharest schools. The research method was the survey, and the technique used was the structured interview, with its instrument - the self-completed written questionnaire. The great majority of the questions were pre-coded, and we used the Likert scale to differentiate between the evaluations. 
Simultaneously to this study, we conducted a qualitative research with class tutors and other high school teachers with no administrative positions. We used the method of free, semi-structured discussion, based on the technique of the in-depth interview, using as an instrument the interview guide. Based on the experience of the authors and in direct relation to the topic of research, we have articulated the following hypotheses:

$\mathrm{H} 1$ - the career orientation of high school students takes central place in the educational work conducted by the teachers;

$\mathrm{H} 2$ - the school provides the optimum frame for the career orientation of its future graduates through its organizational structures and through the partnerships created with different universities;

H3 - there is a clear perspective on the brand of a university among the high school teachers, and it is based on this that high school students are guided and given the means to choose an educational trajectory;

$\mathrm{H} 4$ - universities undertake intense activity in order to promote their brand to the teachers and students in high schools.

Based on the two researches undertaken, we have come to reasonably clear answers in terms of the objectives of the quantitative research and we have tested the hypotheses of the qualitative study.

\section{Results}

In terms of quantitative research, in this study, we have used a questionnaire, given to three hundred and forty-three pupils and then, we've analysed three hundred and twenty-two answers, out of the totality of answers received, due to a lack of full responses. We used SPSS Statistics Program for the frequency distribution.

We will analyze three different aspects related to the motivation of the pupils in choosing a faculty or a university. We will take into consideration the scales to a very large extent and to a large extent, noting the results with the highest frequency.

First, we examined what determines pupils to choose a field or a faculty.

Table 1. The safety and future of my profession on the labor market

\begin{tabular}{|ll|l|l|l|l|}
\hline & Frequency & Percent & Valid Percent & Cumulative Percent \\
\hline \multirow{6}{*}{ Valid } & To a very small extent & 13 & 4,0 & 4,0 & 4,0 \\
& To a small extent & 18 & 5,6 & 5,6 & 9,6 \\
& To a moderate extent & 82 & 25,5 & 25,5 & 35,1 \\
& To a large extent & 110 & 34,2 & 34,2 & 69,3 \\
To a very large extent & 99 & 30,7 & 30,7 & 100,0 \\
Total & 322 & 100,0 & 100,0 & \\
\hline
\end{tabular}

Source: Authors' own research.

As we can observe, $30,7 \%$ of the respondents appreciated the safety and future of the profession on the labor market as being to a very large extent important and $34,2 \%$ as being important to a large extent. 
Table 2. Estimated material benefits

\begin{tabular}{|ll|l|l|l|l|}
\hline & Frequency & Percent & Valid Percent & Cumulative Percent \\
\hline \multirow{6}{*}{ Valid a very small extent } & 14 & 4,3 & 4,3 & 4,3 \\
& To a small extent & 40 & 12,4 & 12,4 & 16,8 \\
& To a moderate extent & 105 & 32,6 & 32,6 & 49,4 \\
& To a large extent & 111 & 34,5 & 34,5 & 83,9 \\
To a very large extent & 52 & 16,1 & 16,1 & 100,0 \\
Total & 322 & 100,0 & 100,0 & \\
\hline
\end{tabular}

Source: Authors' own research.

Regarding the estimated material benefits, the majority of the students, namely 34 , $5 \%$ appreciated them as being important to a large extent.

Table 3. The desire to do what I like

\begin{tabular}{|ll|l|l|l|l|}
\hline & Frequency & Percent & Valid Percent & Cumulative Percent \\
\hline \multirow{6}{*}{ Volid } & To very small extent & 7 & 2,2 & 2,2 & 2,2 \\
& To a small extent & 4 & 1,2 & 1,2 & 3,4 \\
To a moderate extent & 17 & 5,3 & 5,3 & 8,7 \\
& To a large extent & 57 & 17,7 & 17,7 & 26,4 \\
To a very large extent & 237 & 73,6 & 73,6 & 100,0 \\
Total & 322 & 100,0 & 100,0 & \\
\hline
\end{tabular}

Source: Authors' own research.

In conclusion, analyzing the most frequent responses, we can observe that the most important aspect that pupils take into consideration when they choose a study field, namely a faculty, is their desire to do what they want (91,3\%). Other important aspects for them are the safety and future of the profession on the labor market $(64,6 \%)$ and the material benefits $(50,6 \%)$ they will have.

Further, we examined the criteria for choosing a university.

Table 4. University prestige

\begin{tabular}{|ll|l|l|l|l|}
\hline & Frequency & Percent & Valid Percent & Cumulative Percent \\
\hline \multirow{6}{*}{ Valid } & To a very small extent & 11 & 3,4 & 3,4 & 3,4 \\
& To a small extent & 13 & 4,0 & 4,0 & 7,5 \\
To a moderate extent & 96 & 29,8 & 29,8 & 37,3 \\
To a large extent & 133 & 41,3 & 41,3 & 78,6 \\
To a very large extent & 69 & 21,4 & 21,4 & 100,0 \\
Total & 322 & 100,0 & 100,0 & \\
\hline
\end{tabular}

Source: Authors' own research.

Regarding the university prestige, most of the pupils $(41,3 \%)$ appreciated it as being important to a large extent.

\section{Table 5. The opportunity to access scholarships}

\begin{tabular}{|ll|l|l|l|l|}
\hline & & Frequency & Percent & Valid Percent & Cumulative Percent \\
\hline \multirow{4}{*}{ Valid } & To a very small extent & 29 & 9,0 & 9,0 & 9,0 \\
& To a small extent & 40 & 12,4 & 12,4 & 21,4 \\
& To a moderate extent & 111 & 34,5 & 34,5 & 55,9 \\
& To a large extent & 100 & 31,1 & 31,1 & 87,0
\end{tabular}




\begin{tabular}{|l|l|l|l|l|}
\hline To a very large extent & 42 & 13,0 & 13,0 & 100,0 \\
Total & 322 & 100,0 & 100,0 & \\
\hline
\end{tabular}

Source: Authors' own research.

As we can see $34,5 \%$ of the respondents consider that the opportunity to access scholarships is an important criteria when choosing a university.

Table 6. The opportunity to access internships

\begin{tabular}{|ll|l|l|l|l|}
\hline & Frequency & Percent & Valid Percent & Cumulative Percent \\
\hline \multirow{6}{*}{ Valid } & To a very small extent & 29 & 9,0 & 9,0 & 9,0 \\
& To a small extent & 49 & 15,2 & 15,2 & 24,2 \\
& To a moderate extent & 95 & 29,5 & 29,5 & 53,7 \\
& To a large extent & 93 & 28,9 & 28,9 & 82,6 \\
& To a very large extent & 56 & 17,4 & 17,4 & 100,0 \\
& Total & 322 & 100,0 & 100,0 & \\
\hline
\end{tabular}

Source: Authors' own research.

$29,5 \%$ of the respondents take into account to a moderate extent the opportunity to access internships when choosing a university.

Table 7. Quality academic programs

\begin{tabular}{|ll|l|l|l|l|}
\hline & Frequency & Percent & Valid Percent & Cumulative Percent \\
\hline \multirow{6}{*}{ Valid } & To a very small extent & 8 & 2,5 & 2,5 & 2,5 \\
& To a small extent & 15 & 4,7 & 4,7 & 7,1 \\
& To a moderate extent & 77 & 23,9 & 23,9 & 31,1 \\
& To a large extent & 112 & 34,8 & 34,8 & 65,8 \\
& To a very large extent & 110 & 34,2 & 34,2 & 100,0 \\
& Total & 322 & 100,0 & 100,0 & \\
\hline
\end{tabular}

Source: Authors' own research.

Taking into consideration the responses, given by the pupils, one can see that the most important criteria by which they choose a university are the quality academic programs $(69,1 \%)$ and the prestige of the university $(62,7 \%)$, followed by the opportunity to access internships $(46,3 \%)$ and the opportunity to access scholarships $(44,1 \%)$.

Finally, we analyzed students' perceptions of how universities should provide information and promote themselves.

Table 8. Organizing meetings with students and pupils

\begin{tabular}{|c|c|c|c|c|c|}
\hline & & Frequency & Percent & $\begin{array}{l}\text { Valid } \\
\text { Percent }\end{array}$ & Cumulative Percent \\
\hline $\begin{array}{l}\text { Valid } \\
\text { Missing } \\
\text { Total }\end{array}$ & $\begin{array}{l}\text { To a very small extent } \\
\text { To a small extent } \\
\text { To a moderate extent } \\
\text { To a large extent } \\
\text { To a very large extent } \\
\text { Total } \\
\text { System }\end{array}$ & $\begin{array}{l}9 \\
19 \\
107 \\
124 \\
63 \\
322 \\
10 \\
332\end{array}$ & \begin{tabular}{|l}
2,7 \\
5,7 \\
32,2 \\
37,3 \\
19,0 \\
97,0 \\
3,0 \\
100,0
\end{tabular} & $\begin{array}{l}2,8 \\
5,9 \\
33,2 \\
38,5 \\
19,6 \\
100,0\end{array}$ & \begin{tabular}{|l}
2,8 \\
8,7 \\
41,9 \\
80,4 \\
100,0
\end{tabular} \\
\hline
\end{tabular}

Source: Authors' own research.

Meetings with students and pupils is important to a moderate extent for $37,3 \%$ of the respondents. 
Table 9. Organizing meetings with professors and pupils

\begin{tabular}{|ll|l|l|l|l|}
\hline & & Frequency & Percent & $\begin{array}{l}\text { Valid } \\
\text { Percent }\end{array}$ & Cumulative Percent \\
\hline \multirow{6}{*}{ Valid } & To a very small extent & 17 & 5,1 & 5,3 & 5,3 \\
& To a small extent & 20 & 6,0 & 6,2 & 11,5 \\
& To a moderate extent & 88 & 26,5 & 27,3 & 38,8 \\
& To a large extent & 124 & 37,3 & 38,5 & 77,3 \\
Missing & To a very large extent & 73 & 22,0 & 22,7 & 100,0 \\
Total & Total & 322 & 97,0 & 100,0 & \\
\hline
\end{tabular}

Regarding the meeting with professors and pupils, the majority of the pupils, namely $37,3 \%$ consider that this kind of actions are important to a large extent.

Table 10. Organizing visits inside the university

\begin{tabular}{|ll|l|l|l|l|}
\hline & & Frequency & Percent & $\begin{array}{l}\text { Valid } \\
\text { Percent }\end{array}$ & Cumulative Percent \\
\hline \multirow{6}{*}{ Valid } & To a very small extent & 6 & 1,8 & 1,9 & 1,9 \\
& To a small extent & 18 & 5,4 & 5,6 & 7,5 \\
& To a moderate extent & 60 & 18,1 & 18,6 & 26,1 \\
& To a large extent & 139 & 41,9 & 43,2 & 69,3 \\
Missing & To a very large extent & 99 & 29,8 & 30,7 & 100,0 \\
Total & Total & 322 & 97,0 & 100,0 & \\
\hline
\end{tabular}

Source: Authors' own research.

Organizing visits inside the university represents an important action (to a large extent) for $41,9 \%$ of the pupils.

Table 11. Organizing university open doors

\begin{tabular}{|c|c|c|c|c|c|}
\hline & & Frequency & Percent & \begin{tabular}{|l} 
Valid \\
Percent
\end{tabular} & Cumulative Percent \\
\hline $\begin{array}{l}\text { Valid } \\
\\
\text { Missing } \\
\text { Total }\end{array}$ & $\begin{array}{l}\text { To a very small extent } \\
\text { To a small extent } \\
\text { To a moderate extent } \\
\text { To a large extent } \\
\text { To a very large extent } \\
\text { Total } \\
\text { System }\end{array}$ & $\begin{array}{l}9 \\
20 \\
64 \\
113 \\
116 \\
322 \\
10 \\
332\end{array}$ & \begin{tabular}{|l}
2,7 \\
6,0 \\
19,3 \\
34,0 \\
34,9 \\
97,0 \\
3,0 \\
100,0
\end{tabular} & $\begin{array}{l}2,8 \\
6,2 \\
19,9 \\
35,1 \\
36,0 \\
100,0\end{array}$ & $\begin{array}{l}2,8 \\
9,0 \\
28,9 \\
64,0 \\
100,0\end{array}$ \\
\hline
\end{tabular}

Source: Authors' own research.

Organizing university open doors is important to a very large extent for $34,9 \%$ of the respondents. 
Table 12. Allowing us to participate at different courses

\begin{tabular}{|c|c|c|c|c|c|}
\hline & & Frequency & Percent & $\begin{array}{l}\text { Valid } \\
\text { Percent }\end{array}$ & Cumulative Percent \\
\hline $\begin{array}{l}\text { Valid } \\
\text { Missing } \\
\text { Total }\end{array}$ & $\begin{array}{l}\text { To a very small extent } \\
\text { To a small extent } \\
\text { To a moderate extent } \\
\text { To a large extent } \\
\text { To a very large extent } \\
\text { Total } \\
\text { System }\end{array}$ & \begin{tabular}{|l}
9 \\
26 \\
63 \\
85 \\
139 \\
322 \\
10 \\
332 \\
\end{tabular} & \begin{tabular}{|l|}
2,7 \\
7,8 \\
19,0 \\
25,6 \\
41,9 \\
97,0 \\
3,0 \\
100,0
\end{tabular} & $\begin{array}{l}2,8 \\
8,1 \\
19,6 \\
26,4 \\
43,2 \\
100,0\end{array}$ & $\begin{array}{l}2,8 \\
10,9 \\
30,4 \\
56,8 \\
100,0\end{array}$ \\
\hline
\end{tabular}

PICBE | 790

The most important activities which a university should undertake to share information about their offers are organizing visits inside the university (71.7\%), organizing university open doors (68.9\%), allowing pupils to participate at different courses (67.5\%) and meetings with professors (59.3) and students (56.3).

In terms of qualitative research, in this study, we have used the interview guide., given with ten homeroom teachers and then, we've analysed eight answers, out of the totality of answers received, due to a lack of full responses. The aim of this qualitative research was to monitor the homeroom teachers' real interest in the professional orientation of their students, and the existence of certain professional orientation activities in high schools. We came up with four hypotheses, two of which were confirmed while the other two were invalidated.

The first hypothesis stated that the students' professional orientation was central to the educational work carried out by the teaching staff - a hypothesis that was invalidated once the answers received were analysed. Due to the current psychological - social climate existing in most schools, the short interaction time between students and their homeroom teachers and due to an overall lack of awareness on how important counselling and orientation activities are for students, there is simply not enough attention paid to supporting students in choosing their educational path. Although, most of our respondents stated that, students' professional orientation was an important aspect of their educational work, the topics discussed during homeroom classes were mostly social topics.

The second hypothesis, stating that the schooling system, through its organisational structures and its partnerships concluded with various universities, provided an optimal environment for the professional orientation of its future graduates, was also invalidated. Most respondents stated that the school had no coherent vision related to the professional orientation of its future alumni. Although some high schools have their own professional counselling and orientation centres, the specialists working there do not have the necessary resources at their disposal, to include a large number of pupils in their professional guidance activities.

We must specify that, our analysis of the answers received, revealed the existence of a partnership between the Goethe German College and the Faculty of Business Administration taught in foreign languages - this being one of the very few positive examples in the field. 
The third hypothesis - stating that the teaching staff had a very clear idea of most university brands and all the ways and means of orientation used to guide students in their quest to select an educational direction, were based on these brands - was confirmed. In most respondents' opinion, the brand of a university is associated with its notoriety, with the prestige of its academic professors, with the prospects of professional development provided to its graduates and the toughness of its educational process. Most respondents think that there is a real need for partnerships to be concluded between universities and lower education schools, and both sides must be interested in such partnerships, in order to generate an open, constant and well-structured exchange of information. We must specify that, the Bucharest University of Economic Studies and the National University of Political Studies and Public Administration have been described as being actively interested in such partnerships.

The last hypothesis, stating that universities were intensively involved in advertising activities meant to promote their brands among the teaching staff and among the pupils studying in lower education institutions, was also confirmed. Among the answers received from our respondents, we can highlight as a positive fact, the periodic efforts made by the Bucharest University of Economic Studies to promote its educational offer by various means.

\section{Conclusions}

Regarding the conclusions of the quantitative research we can claim firstly that a university plays an important role for pupils even before they are students. Both schools and universities should make an effort to ease pupil's career decisions. Universities should build a strong brand, because as one can see, it is of great importance for pupils. Moreover they need to market themselves as never before and find several ways to share information and to promote themselves among the most important recruitment pool. By creating a positive and lasting perception of a university and moreover by building a strong identity, universities must differentiate from others and become able to attract as many good students as possible.

When it comes to the conclusions of this qualitative research, we can state, firstly, the importance of consistency and harmonisation in planning and carrying out certain coherent communication measures between the pre-university and the university educational systems, which would lead to adequate guidance provided to students, in choosing their career paths. Thus, a change of perception over career counselling and orientation activities provided to future graduates, and the school's and the teaching staff's permanent involvement in students' professional lives, by various activities, might generate an optimal environment for the young Romanian generation to enjoy a healthy professional development. Besides, a specific Marketing programme drafted at university or even at each faculty level, might boost the university brand promotion among high schools, thus attracting as many young students as possible, eager to forge a brilliant career, to develop their potential to a maximum and to satisfy their intellectual needs.

\section{Bibliography}

Armstrong, G., Kotler, Ph. (2015). Introducere în marketing, Ediția a 12-a, Boston, Columbus, Indianopolis etc.,: Pearson Publishing. 
Băcilă, M. Fl. (2013). Cercetări de marketing în instituțiile de învățământ superior, ClujNapoca: Editura Romprest.

Bogdan, A. (2011). Branding pe frontul de est. Despre reputație împotriva curentului, București, Editura Brandient.

Bruhn, M., Köhler, R. (2010). Wie Marken wirken. Impulse aus Neuroökonomie für die Markenführung, München: Fr. Vahlen Verlag.

De Chernatony, L., \& Dall'Olmo Riley, F. (1998). Defining a" brand": Beyond the literature with experts' interpretations. Journal of Marketing Management, 14(5), 417-443.

Erisher, W., Obert, H. H., Frank, G. (2014). Brand reputation management within Higher Education Sector: A Review of the Literature on Higher Education Brand Reputation Management, International Research Journal of Marketing, 2(1), 1-27.

Esch, Fr., Hermann, A., Sattler, H. (2008). Marketing. Einemanagementorientierte Einführung, 2. Aufl., München: Fr. Vahlen Verlag.

Grigorescu, A., Bob, C. A., Dobrescu, E. M.(2007). Marketingul afacerilor publice și private, București: Editura Uranus.

Hanna, S. (2008). An analysis of terminology use in place branding, London, New York, Shanghai: Palgave McMillan.

IRIMIEŞ, C. (2012). Brand Evaluation-A Basic Feature in Modern Brand Management. Transylvanian Review of Administrative Sciences, 8(37), 80-94.

Kotler, Ph., Heider, D. H., Rein, I. (1993). Marketing Places: Attracting Investment, Industry And Tourism To Cities, States And Nations, New York: Free Press.

Petre, 0. (2015) [How do students choose their faculties]Available online: http://www.ddresearch.ro/cum-isi-aleg-tinerii-facultatea-we-have-all-the-insights/

Popa, A., \& Pelau, C. (2016). Differences in the clothing brand perception depending on generation/Diferente în perceptia brandurilor de îmbracaminte în functie de generatie. Industria Textila, 67(4), 260.

Pop, N. A., Todor, M. D., \& Partenie, C. V. (2015). The Marketing Mentality Within The Organization-A Comparative Study Between Companies And Non-Profit Organizations In Romania. Ann Univ Oradea Econ Sci, 1(1), 1260-1268.

Veloutsou, C., Levis, J., Paton, R., (2005). University selection and information requirement and importance, The International Journal of Educational Management, Hoboken, New Jersey.

Voineag, V., Pelău, C., Șerban, D. (2017). Research regarding the Correlation among Factors influencing the Satisfaction of Stdents in a University, Economic Computation and Economic Cybernetics Studies and Research, 51(2), 55-66.

State, A.. M. (2016). Comunicarea narativă și identitatea brandingului universitar, Revista română de sociologie, serie nouă, an XXVII, nr. 3-4.

Tybout, M. A., Calkins, T., (Editors) (2005), Kellog on Btanding, New jersey: John Wiley \& Sons, Inc., Hoboken.

Zyman, S., Brott, A. (2008). Sfârșitul advertisingului așa cum îl știm, București: Editura Publica.

Fan, Y. (2010). Branding the nation: Towards a better understanding. Place branding and public diplomacy, 6(2), 97-103.

Wheeler, A. (2009). Designing brand identity: An essential guide for the whole branding team, 3rd Edition, New Jersey: John Wiley \& Sons, Hoboken. 